\title{
Comparison of Mechanical Properties of PLA and ABS Based Structures Produced by Fused Deposition Modelling Additive Manufacturing
}

\author{
Koray Özsoy ${ }^{*}$, Ali Erçetin ${ }^{2}$, Zihni Alp Çevik ${ }^{3}$ \\ ${ }^{1 *}$ Isparta University of Applied Sciences, Senirkent Vocational School, Department of Electricity and Energy, Isparta, Turkey, (ORCID: 0000-0001-8663-4466), \\ korayozsoy@isparta.edu.tr \\ 2 Bingöl University, Faculty of Engineering and Architecture, Department of Mechanical Engineering, Bingol, Turkey, (ORCID: 0000-0002-7631-1361), \\ aliercetin@bingol.edu.tr \\ ${ }^{3}$ Adiyaman University, Besni Vocational School, Department of Mechatronics, Adıyaman, Turkey, (ORCID: 0000-0003-3141-0160), zcevik@adiyaman.edu.tr
}

(First received 16 August 2021 and in final form 7 November 2021)

(DOI: $10.31590 /$ ejosat.983317)

ATIF/REFERENCE: Özsoy, K., Erçetin, A. \& Çevik, Z.A. (2021). Comparison of mechanical properties of PLA and ABS based structures produced by fused deposition modelling additive manufacturing. European Journal of Science and Technology, (27), 802809.

\begin{abstract}
Fused deposition modelling (FDM) additive manufacturing is a technology that works horizontally and vertically in which an extrusion nozzle moves on a building platform. Knowing the mechanical properties of the parts manufactured by the FDM method is very important for the parts to work efficiently in places of usage. Additive manufacturing with the FDM method is widespread due to its advantages such as easy-to-use features, low cost, flexibility in material options, and less processing after printing. Two different polymer materials (PLA and ABS), tensile, compression test and 3 point bending tests, a total of 36 test specimens were printed on the FDM type printer. The samples obtained were subjected to mechanical tests to determine their mechanical properties. As a result of the study, the effect of the samples' mechanical properties produced by the PLA and ABS-based FDM method was examined and compared with the literature. The results showed that the mechanical properties of PLA and ABS material are highly dependent on the filling density. While the mechanical properties were improved by the increase in filling density rate, the print speed has been decreased. The research findings obtained are of a nature that will guide the optimization of the FDM method's parts in terms of mechanical properties.
\end{abstract}

Keywords: Additive Manufacturing, Fused Deposition Modelling, PLA, ABS, Tensile Strength, 3-Point Bending.

\section{Eriyik Yığma Modellemesi Eklemeli İmalat ile Üretilen PLA ve ABS Esaslı Yapıların Mekanik Özelliklerinin Karşılaştırılması}

$\ddot{O} \mathbf{z}$

Eriyik yığma Modellemesi (FDM), bir ekstrüzyon nozulunun bir inşa platformu üzerinde hareket ettiği yatay ve dikey olarak çalışan bir teknolojidir. FDM yöntemiyle üretilen parçaların mekanik özelliklerinin bilinmesi, parçaların kullanım yerlerinde verimli çalışabilmesi için çok önemlidir. FDM yöntemi ile eklemeli imalat, kolay kullanım özellikleri, düşük maliyeti, malzeme seçeneklerinde esneklik ve baskı sonrası daha az işlem yapılması gibi avantajları nedeniyle yaygın olarak kullanılmaktadır. FDM tipi yazıcıda iki farklı polimer malzeme (PLA ve ABS), çekme, basma testi ve 3 nokta eğilme testleri olmak üzere toplam 36 adet test numunesi basılmıştır. Elde edilen numuneler mekanik özelliklerini belirlemek için mekanik testlere tabi tutulmuştur. Çalışma sonucunda PLA ve ABS esaslı FDM yöntemi ile üretilen numunelerin mekanik özelliklerine etkisi incelenmiş ve literatür ile karşılaştırılmıştır. Elde edilen araştırma bulguları, FDM yönteminin parçalarının mekanik özellikler açısından optimizasyonuna rehberlik edecek niteliktedir.

Anahtar Kelimeler: Eklemeli İmalat, Eriyik Yığma Modellemesi, PLA, ABS, Çekme Dayanımı, 3-Nokta Eğme.

* Corresponding Author: korayozsoy@isparta.edu.tr 


\section{Introduction}

Additive manufacturing (AM) is a manufacturing method that has entered our lives as a result of the inadequacy of traditional methods and allows the three-dimensional model drawn with computer-aided design to be presented as a product (Nagesha et al., 2020; Çevik et al., 2021). In the AM process, using the model data, a three-dimensional model is produced as a result of adding the material layer by layer (Jiang et al., 2019). The rapid production of parts with complex geometries provides freedom and development in design due to the AM method (Allevi et al., 2019). AM processes are divided into seven categories according to the American Society for Testing and Materials (ASTM) standard. These are classified as binder jetting (BJ), directed energy deposition (DED), material extrusion (ME), material jetting, powder bed fusion (PBF), sheet lamination (SL) and photopolymerization (Tofail et al., 2018; Jiang et al., 2018). AM methods include different processes according to the material, technique and technology used. Commonly used AM methods include stereolithograpy (SLA), (Gür, 2021) selective laser sintering (SLS), selective laser melting (SLM), fused deposition modeling (FDM), direct metal laser sintering/melting (DMLS/M) technologies (Gardan, 2016; Celebi et al., 2020). Besides, microelectromechanical (MEMS) and actuator systems are also being fabricated with AM techniques (Ertugrul et al., 2020).

Staratasys founder Scott Crump has developed a 3D manufacturing system inspired by his young child playing with colorful play dough. The main name of this technique, which emerged in 1988, is "Fused Deposition Modeling (FDM). Stratasys company produced its first commercial device in 1991 (Stratasys 1998). FDM is one of the 3D printing technology methods and constitutes $40 \%$ of the systems used in the industry in the world (Damodaran et al., 2021). It is a system based on the principle that the layer formed by melting fibrous thermoplastic materials is suddenly cooled and adhered to the previous layer (Burns, 1991). The plastic fiber material, wound on a roll, is fed into the heated FDM head.

In the FDM method, polymer-based material is widely used because of its easy accessibility and low cost. The most common raw materials are Acrylonitrile Butadiene Styrene (ABS) (Çelik et al., 2021), PolyLactic Acid (PLA) (Boğa et al., 2021),
PolyCarbonate (PC), PC/ABS mixture, epoxy, epoxy resins, polyamide (nylon), thermoset and thermoplastic polyurethane. Thermoplastic polymers are used in material extrusion and powder bed melting methods. In the material extrusion method, complex thermoplastics and semi-crystalline polymers are ideally specified in the powder bed melting method. Complex thermoplastics (ABS, PLA, etc.) are high temperature resins and have a randomly arranged molecular structure that does not have a sharp melting point. Therefore, there is a wide viscosity range and temperature control can be done easily in methods such as FDM (Demiray et al., 2018).

Studies on the effect of parameters and fill rates on mechanical properties are continuing in the production of $3 \mathrm{D}$ printed components (Yeşil, et al., 2018; Kaptan et al., 2020; Küçükoğlu et al., 2021). However, more detailed studies are still needed. In addition, there is a lack in the literature on comparative analysis of the mechanical properties of popularly used materials such as ABS and PLA.

This study is about examining the processing parameters and material properties of the FDM 3D printing method, which is one of the additive manufacturing methods. Test samples were drawn according to ISO standards for plastics. With the FDM 3D printing method, tensile, compression and bending test specimens containing PLA and ABS materials were produced according to the test standards. Production parameters were chosen as 0.15-0.2 mm layer thickness, $50 \%$ and $70 \%$ fill rate, 0.8 and $1.2 \mathrm{~mm}$ wall thicknesses, $50 \mathrm{~mm} / \mathrm{sec}$ printing speed, $220{ }^{0} \mathrm{C}$ nozzle temperature, $60{ }^{0} \mathrm{C}$ table temperature. Twelve tensile, compression and bending tests were performed with three repetitions for each processing parameter of PLA and ABS material. The obtained results were compared with the literature.

\section{Material and Method}

\subsection{Material}

In the study, PLA and ABS flaments were used as workpiece materials and the general properties are given in Table 1. The experimental specimens containing PLA and ABS materials were produced using the Teira $3 \mathrm{D}$ brand FDM type printer device as shown in Figure 1.

Table 1. Properties of PLA+ and ABS filament

\begin{tabular}{lllllll}
\hline $\begin{array}{l}\text { Printing } \\
\text { temperature } \\
\left({ }^{\circ} \mathrm{C}\right)\end{array}$ & $\begin{array}{l}\text { Density } \\
(\mathrm{g} / \mathrm{cm} 3)\end{array}$ & $\begin{array}{l}\text { Distortion } \\
\text { temperature } \\
\left({ }^{\circ} \mathrm{C}, 0.45 \mathrm{MPa}\right)\end{array}$ & $\begin{array}{l}\text { Tensile } \\
\text { Strength } \\
(\mathrm{MPa})\end{array}$ & $\begin{array}{l}\text { Elongation } \\
\text { at break } \\
(\%)\end{array}$ & $\begin{array}{l}\text { Bending } \\
\text { Strength } \\
(\mathrm{MPa})\end{array}$ & $\begin{array}{l}\text { Impact } \\
\text { resistance } \\
(\mathrm{kJ} / \mathrm{m} 2)\end{array}$ \\
\hline $205-225$ & 1.24 & 52 & 60 & 29 & 87 & 7.0 \\
\hline $210-250$ & 1.04 & 98 & 40 & 40 & 73 & 7.7 \\
\hline
\end{tabular}




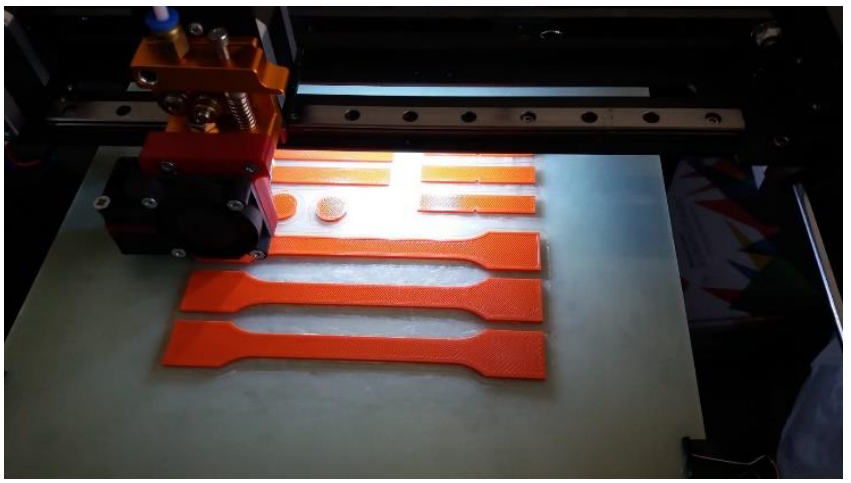

Figure 1. Manufacturing image of FDM 3D printing

Figure 2 shows technical drawing and dimensions of the test specimens in ISO 527: 1993 standard for tensile strength test, in ISO 604:2002 standard for compressive test, in ISO 178:2001 standard for 3 point bending test of the samples fabricated FDM 3D printer, respectively (Pilipovic et al. 2009). Manufacturing parameters in FDM additive manufacturing using both PLA and ABS materials are given in Table 2.

Tensile test was conducted in a test machine (AGS-X, Shimadzu Co., Kyoto, Japan) with a $10 \mathrm{kN}$ force transducer capacity as shown in Figure 2. Tensile test employed two grips (one fixed grip and one movable grip) to hold the specimens, the specific testing parameters for the tensile test were carried out at a pull rate of $1 \mathrm{~mm} / \mathrm{s}$. To minimize the experimental errors, three test specimens were used for each parameter and the average value was accepted as the real value of applied parameter.

\subsection{Method}

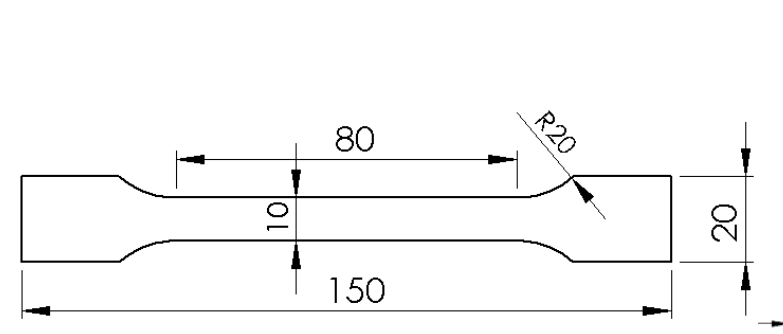

(a)

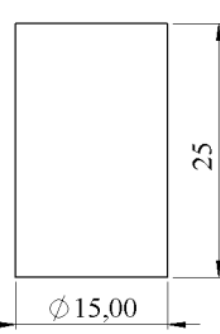

(b)

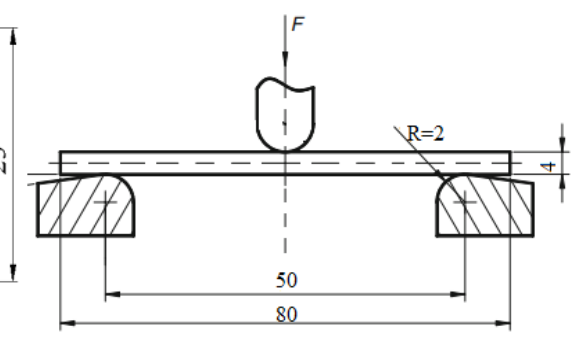

(c)

Figure 2. The specimen dimensions ( $\mathrm{mm}$ ) for a) tensile test, b) compressive test, c) 3 point bending test

Table 2. Manufacturing parameters in FDM additive manufacturing method using both PLA and ABS materials

\begin{tabular}{ccccccc}
\hline PLA/ABS & $\begin{array}{c}\text { Fill Density } \\
(\%)\end{array}$ & $\begin{array}{c}\text { Layer } \\
\text { Thickness } \\
(\mathrm{mm})\end{array}$ & $\begin{array}{c}\text { Wall } \\
\text { Thickness } \\
(\mathrm{mm})\end{array}$ & $\begin{array}{c}\text { Print Speed } \\
(\mathrm{mm} / \mathrm{s})\end{array}$ & $\begin{array}{c}\text { Nozzle } \\
\text { Temperature } \\
\left({ }^{\circ} \mathrm{C}\right)\end{array}$ & $\begin{array}{c}\text { Table } \\
\text { Temperature } \\
\left({ }^{\circ} \mathrm{C}\right)\end{array}$ \\
\hline 1 & 70 & 0,2 & 1,2 & 50 & 220 & 60 \\
2 & 50 & 0,15 & 0,8 & 50 & 220 & 60 \\
\hline
\end{tabular}

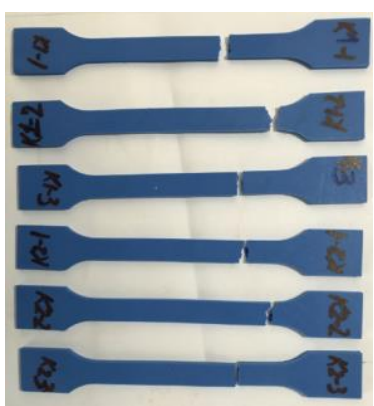

(a)

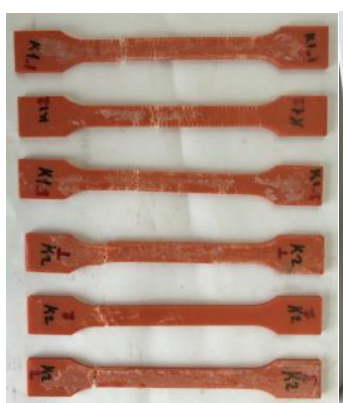

(b)

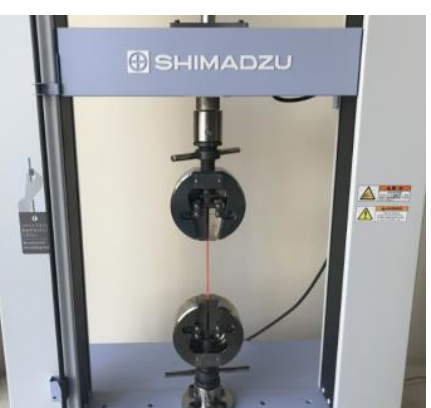

(c)

Figure 2. Images of all components of tensile strength test; a) PLA specimens b) ABS specimens c) experimental setup

A compressive test was conducted in a test machine (AGS-X, Shimadzu Co., Kyoto, Japan) with a $10 \mathrm{kN}$ force transducer capacity as shown in Figure 3. The compression test is essentially the opposite of the tension test in terms of the effects of applying a load on the sample. A constant increasing compression load was applied to both PLA and ABS material specimens placed between two grips in the study. 


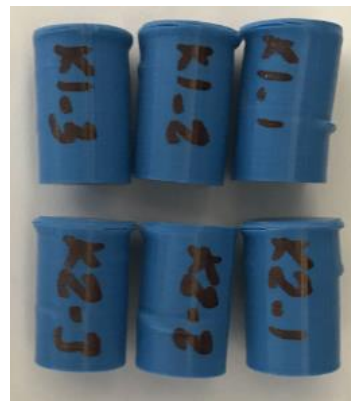

(a)

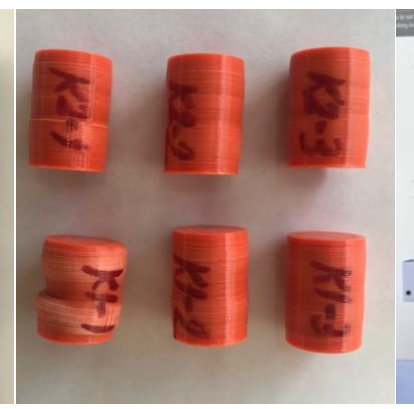

(b)

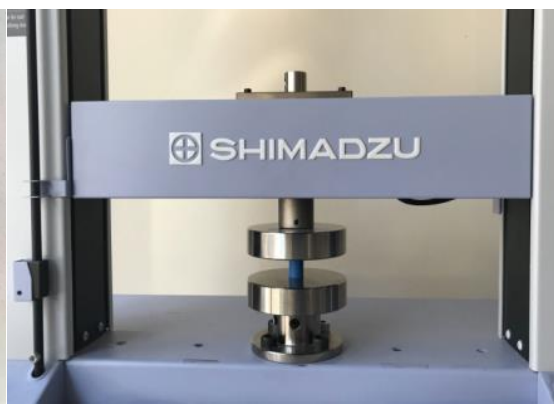

(c)

Figure 3. Images of all components of compressive test; a) PLA specimens b) ABS specimens c) experimental setup

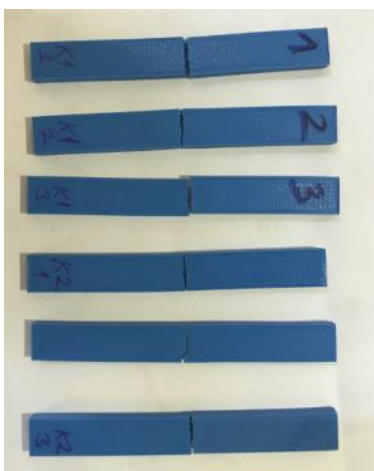

(a)

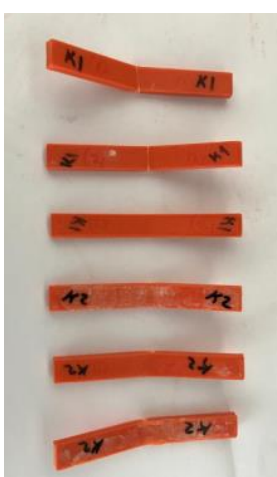

(b)

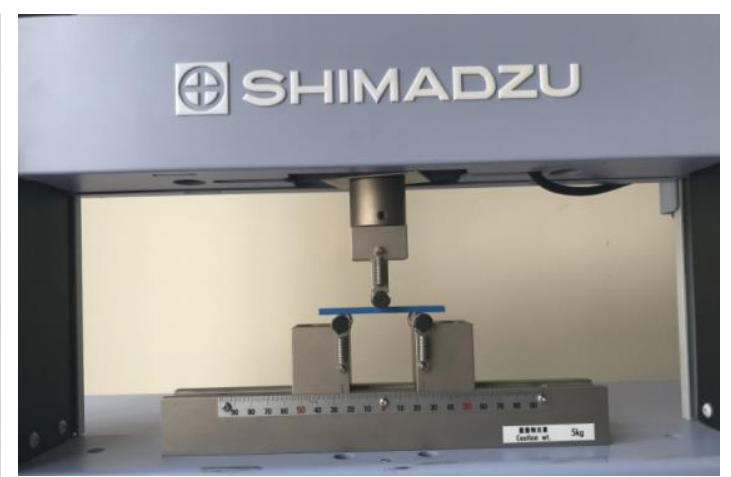

(c)

Figure 4. Images of all components of 3 point bending test; a) PLA specimens b) ABS specimens c) experimental setup

The 3-point bending test is usually performed on brittle materials as a substitute for the tensile test. Therefore, 3-point bending test gives more meaningful results in brittle materials. 3 point bending tests were carried out on the machine (AGS-X, Shimadzu Co., Kyoto, Japan) with a $10 \mathrm{kN}$ force transducer capacity as shown in Figure 4. In the tests, the diameter of the mandrel and the diameter of the supports were fixed in accordance with the standard. After the assemblies were fixed, both PLA and ABS material for 3 point bending test specimens were placed on the supports and the specimens were bent with the help of a mandrel with the application of the load.

\section{Results and Discussions}

Mechanical testing sample groups manufactured by the FDM additive manufacturing method were named according to the mechanical tests to be applied. According to this; the specimen group is named with tensile test specimen group " $\mathrm{T}$ ", the compression test sample group "C", 3-point bending test specimen group with the letter "B". The test results of tensile, compression, and bending specimens manufactured with different process parameters were determined by taking the average of three samples using two different parameters. The research findings were analyzed separately for each mechanical experiment and given in tables.

\subsection{Results of Tensile Strength Tests}

The tensile strength test results obtained from the study are given in Table 3. In Table 3, it is seen that PLA material samples have higher strength values than ABS samples. This is due to the fact that the bond provided between the layers in the sample manufacturing process is better for PLA material samples than ABS samples. In Figure 5, it is seen that the tensile strength of both PLA and ABS material samples increased partially as the fill rate of the samples increased.

Table 3. Results of tensile tests of PLA and ABS material

\begin{tabular}{cccccccc}
\hline PLA & $\begin{array}{c}\text { Elasticity } \\
\text { Module } \\
(\mathrm{GPa})\end{array}$ & $\begin{array}{c}\text { Yield } \\
\text { Strength } \\
(\mathrm{MPa})\end{array}$ & Strain (\%) & ABS & $\begin{array}{c}\text { Elasticity } \\
\text { Module } \\
(\mathrm{GPa})\end{array}$ & $\begin{array}{c}\text { Yield } \\
\text { Strength } \\
(\mathrm{MPa})\end{array}$ & $\begin{array}{c}\text { Strain } \\
(\%)\end{array}$ \\
\hline T1 & 1.094 & 38.32 & 5.67 & $\mathrm{~T} 1$ & 0.704 & 23.45 & 14.14 \\
T2 & 1.039 & 36.21 & 6.40 & $\mathrm{~T} 2$ & 0.681 & 22.68 & 13.52 \\
T3 & 1.082 & 37.32 & 5.53 & $\mathrm{~T} 3$ & 0.676 & 22.82 & 11.51 \\
T4 & 1.072 & 36.87 & 5.71 & $\mathrm{~T} 4$ & 0.603 & 19.86 & 7.45 \\
T5 & 1.104 & 37.41 & 5.40 & $\mathrm{~T} 5$ & 0.624 & 21.29 & 7.66 \\
T6 & 1.089 & 37.81 & 5.86 & T6 & 0.612 & 20.00 & 9.74 \\
\hline Average & 1.080 & 37.33 & 5.76 & Average & 0.65 & 21.68 & 10.67 \\
\hline Standard & 23.01 & 0.73 & 0.351 & Standard & 42.10 & 1.53 & 2.86 \\
Deviation & & & & Deviation & & \\
\hline
\end{tabular}




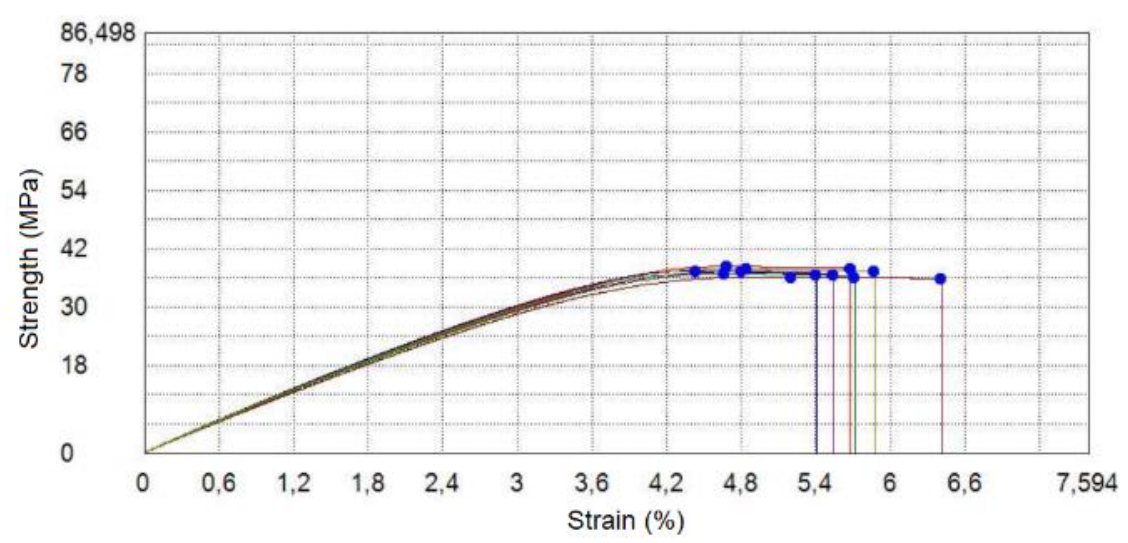

(a)

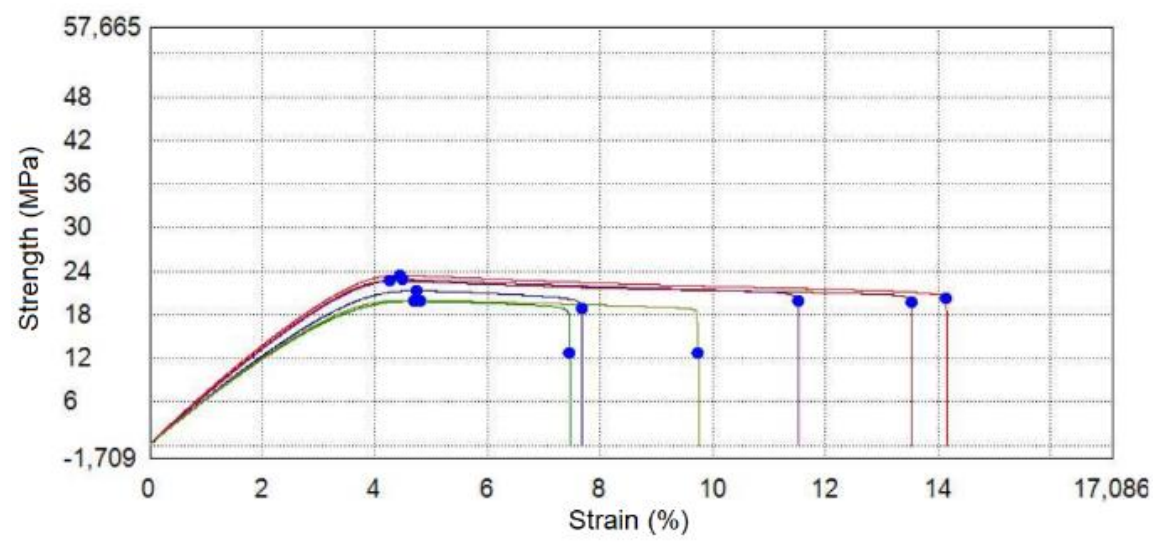

(b)

Figure 5. Stress-strain diagrams of tensile tests for samples manufactured from different parameters a) PLA material, b) ABS material

With the examining of present study and literature studies, in the Svensson study (Svensson, 2017), tensile samples were produced from PLA, ABS, Nylon and TPU materials with the FDM additive manufacturing method and subjected to a tensile test. According to the results obtained, the tensile strengths are 62 $\mathrm{MPa}, 35 \mathrm{MPa}, 29 \mathrm{MPa}$ and $55 \mathrm{MPa}$, respectively (Svensson, 2017). Grabowik et al. (2017) analyzed wood, PLA, ABS, PET, PMMA and ASA filament material group and material properties with tensile tests using FDM additive manufacturing method. In the results of tensile strength for PLA materials, the value of the peak stress is between 38 and $38.4 \mathrm{MPa}$. The value of the strain at peak stress is between 5 and $5.3 \%$. The value of the Young's modulus is between 1074 and $1100 \mathrm{MPa}$. In the results of tensile strength for PLA materials, the value of the peak stress is between 34.6 and $35 \mathrm{MPa}$. The value of the strain at peak stress is between 5.5 and $5.6 \%$. The value of the Young's modulus is between 856 and $864 \mathrm{MPa}$ (Grabowik et al., 2017). While the tensile test results (66.5 MPa) for horizontal, (49.5 MPa) for flat, $(26.1 \mathrm{MPa})$ for vertical values are obtained, the bending test results are (98.6 $\mathrm{MPa}$ ) for horizontal, (93.5 MPa) MPa) for straight and (42.3 MPa) vertical values were obtained (Caminero et al., 2019). The results obtained in the present study are similar to the literature.

\subsection{Results of Compression Tests}

Compression test results obtained from the study are given in Table 4. With the examining the of Table 4, it is seen that PLA material samples have higher compressive strength values than ABS samples. This is due to the differences in the molecular structure of these materials and differences in the number of branches and functional groups of polymers. PLA has a $\mathrm{CH}_{3}$ and $\mathrm{O}_{2}$ group substitutes in materials. This affects the chain entanglement in PLA and increases the glass transition temperature. In addition, as the fill rate increased in PLA and ABS samples, it was observed that the samples were stacked and shortened in the longitudinal section without spreading in the cross section as a result of the compression test. In Figure 6, as the fill rate of the samples decreased, the compressive strength of both PLA and ABS material increased partially. However, the ductility of ABS material shows the rigidity of ABS material and can also be expressed as its resistance to elastic stretching.

Abeykon et al. (2020) have reported that compressive strength values are $32 \mathrm{MPa}$ and $25 \mathrm{MPa}$ for PLA and ABS materials, respectively. The $\%$ strain values are also obtained from $6 \%$ for PLA and $17 \%$ for ABS (Abeykon et al., 2020). Sood et al. (2012) have investigated that ABS P400 material has five important processing parameters such as layer thickness, part orientation, air gap, raster angle and width, and their effects on compressive strength. The maximum compressive strength was obtained as 17.45 MPa by Sood et al., (2012). The obtained compressive strength results do not contradict other studies in the literature. 
European Journal of Science and Technology

\begin{tabular}{cccccccc}
\hline PLA & $\begin{array}{c}\text { Elasticity } \\
\text { Module } \\
(\mathrm{GPa})\end{array}$ & $\begin{array}{c}\text { Yield } \\
\text { Strength } \\
(\mathrm{MPa})\end{array}$ & Strain (\%) & ABS & $\begin{array}{c}\text { Elasticity } \\
\text { Module } \\
(\mathrm{GPa})\end{array}$ & $\begin{array}{c}\text { Yield } \\
\text { Strength } \\
(\mathrm{MPa})\end{array}$ & $\begin{array}{c}\text { Strain } \\
(\%)\end{array}$ \\
\hline $\mathrm{C} 1$ & 0.814 & 29.32 & 5.11 & $\mathrm{C} 1$ & 0.412 & 19.35 & 22.03 \\
$\mathrm{C} 2$ & 0.818 & 32.21 & 5.27 & $\mathrm{C} 2$ & 0.430 & 19.98 & 24.00 \\
$\mathrm{C} 3$ & 0.865 & 34.31 & 5.42 & $\mathrm{C} 3$ & 0.420 & 19.91 & 23.99 \\
$\mathrm{C} 4$ & 0.822 & 30.18 & 5.21 & $\mathrm{C} 4$ & 0.547 & 25.02 & 24.00 \\
$\mathrm{C} 5$ & 0.857 & 34.95 & 5.40 & $\mathrm{C} 5$ & 0.547 & 25.08 & 24.00 \\
$\mathrm{C} 6$ & 0.829 & 33.75 & 5.24 & $\mathrm{C} 6$ & 0.547 & 24.92 & 24.00 \\
\hline Average & 0.834 & 32.45 & 5.27 & Average & 0.484 & 22.38 & 23.67 \\
\hline Standard & 21.59 & 2.29 & 0.12 & $\begin{array}{c}\text { Standard } \\
\text { Deviation }\end{array}$ & 69.26 & 2.88 & 0.80 \\
Deviation & & & & & & & \\
\hline
\end{tabular}

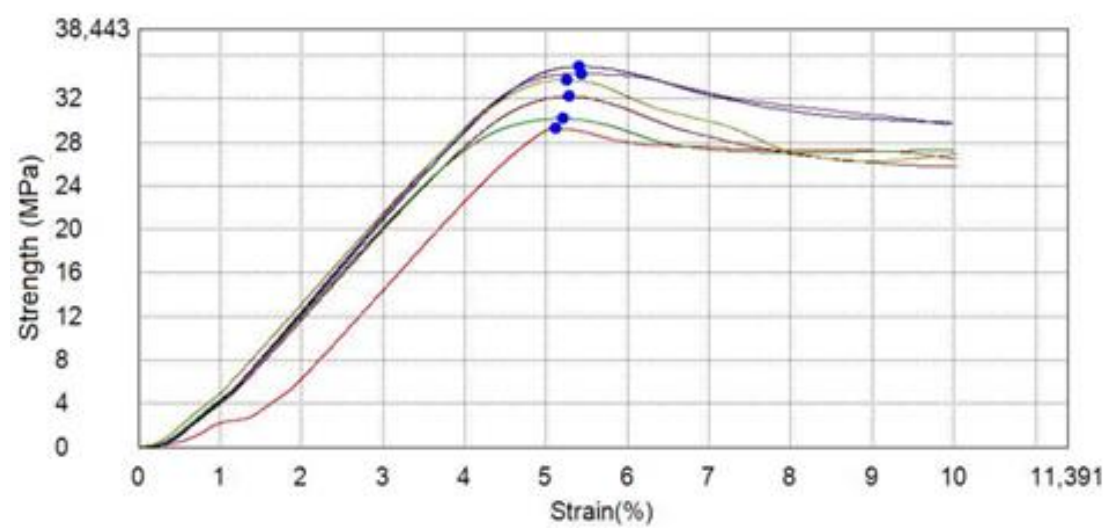

(a)

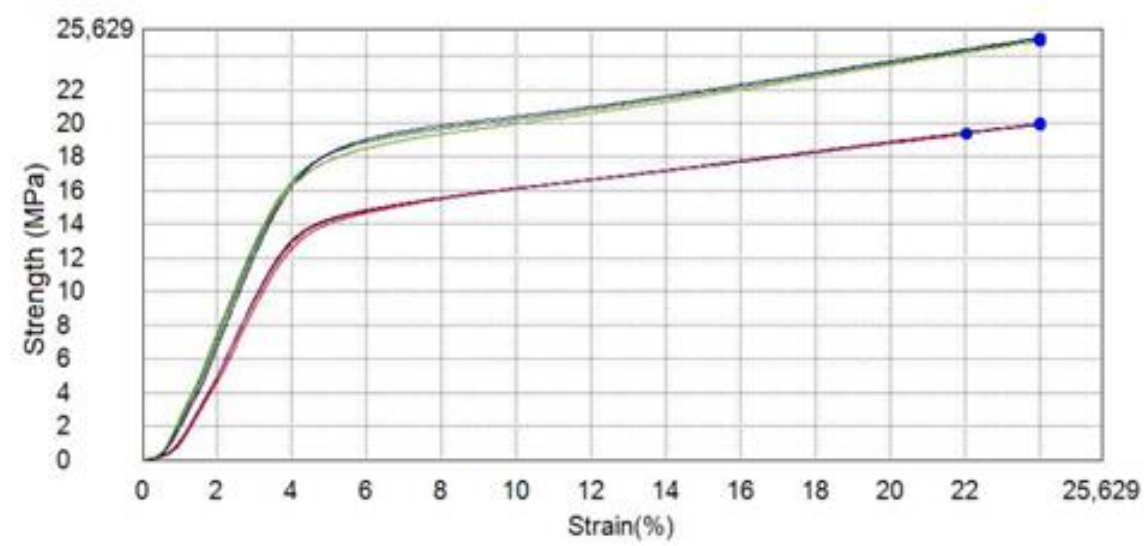

(b)

Figure 6. Stress-strain diagrams of compression tests for samples manufactured from different parameters a) PLA material, b) ABS material

\subsection{Results of 3-Point Bending Tests}

The 3-point bending test results obtained from the study are given in Table 5. Figure 7 shows stress-strain diagrams of samples manufactured from different parameters. It is seen that PLAcontaining samples have higher bending strength values than ABS samples. This is due to differences in the molecular structure of these materials and differences in the number of branches and functional groups of polymers. PLA has a $\mathrm{CH}_{3}$ and $\mathrm{O}_{2}$ group substitutes in materials.

Palic et al. [17] have produced the samples with a layer thickness of $0.1 \mathrm{~mm}$ and $100 \%$ fill rate by FDM method with PLA material. Subsequently, these specimens were subjected to the three-point bending test and the obtained bending strength was 214 MPa (Palic et al., 2019). Caminero et al. (2019) subjected PLA-containing samples to tensile and three-point bending tests.
With the FDM 3D printing method, the production direction has achieved $99 \mathrm{MPa}$ for flat, $94 \mathrm{MPa}$ for the front edge and $43 \mathrm{MPa}$ for upright (Caminero et al., 2019). In a study of Kuznetsov (2018), flexural strengths ranging from a minimum of $17.5 \mathrm{MPa}$ to $70.7 \mathrm{MPa}$ were obtained by changing the layer thickness with PLA material with a nozzle diameter of $0.4,0.6$ and $0.8 \mathrm{~mm}$ (Kuznetsov, 2018). Khuong et al. (2014) studied the bending strength properties of ABS material samples. The average stress values of the bending samples were $21 \mathrm{MPa}$, and the elongation values were in the range of $12-14 \%$ (Khuong et al., 2014). Findings show that the yield strength 3 point bending tests of PLA and ABS materials variable is also related to the filling density, the results obtained are also lower than the literature value in this respect. 
Tablo 5. Results of 3 point bending tests of PLA and ABS materials

\begin{tabular}{cccccccc}
\hline PLA & $\begin{array}{c}\text { Elasticity } \\
\text { Module } \\
(\mathrm{GPa})\end{array}$ & $\begin{array}{c}\text { Yield } \\
\text { Strength } \\
(\mathrm{MPa})\end{array}$ & Strain $(\%)$ & ABS & $\begin{array}{c}\text { Elasticity } \\
\text { Module } \\
(\mathrm{GPa})\end{array}$ & $\begin{array}{c}\text { Yield } \\
\text { Strength } \\
(\mathrm{MPa})\end{array}$ & $\begin{array}{c}\text { Strain } \\
(\%)\end{array}$ \\
\hline B1 & 1.565 & 37.26 & 3.40 & $\mathrm{~B} 1$ & 1.161 & 28.90 & 9.14 \\
$\mathrm{~B} 2$ & 1.596 & 38.76 & 3.32 & $\mathrm{~B} 2$ & 1.156 & 29.39 & 7.88 \\
B3 & 1.568 & 39.61 & 3.91 & $\mathrm{~B} 3$ & 1.052 & 27.69 & 8.36 \\
B4 & 1.522 & 36.99 & 3.53 & $\mathrm{~B} 4$ & 0.996 & 26.27 & 11.30 \\
B5 & 1.535 & 34.95 & 3.42 & $\mathrm{~B} 5$ & 1.089 & 27.30 & 9.21 \\
B6 & 1.496 & 36.79 & 3.61 & B6 & 0.923 & 24.23 & 10.25 \\
\hline Average & 1.547 & 1.63 & 3.53 & Average & 1.063 & 27.30 & 9.36 \\
\hline Standard & 36.18 & 4.66 & 0.21 & Standard \\
Deviation & & & Deviation & 92.60 & 1.87 & 1.25 \\
\hline
\end{tabular}

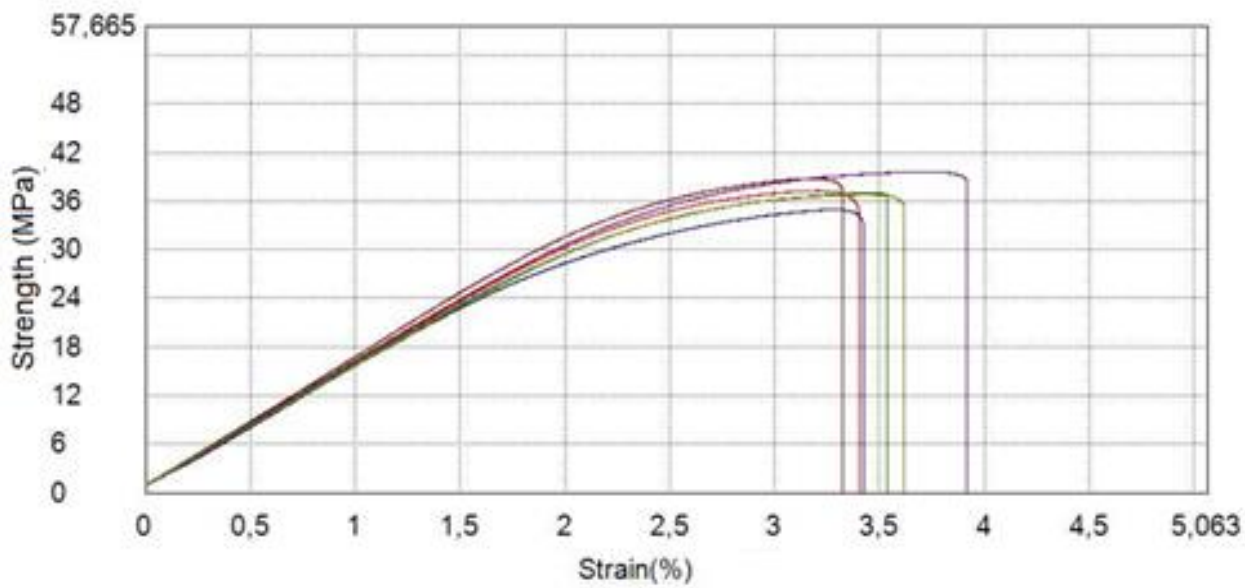

(a)

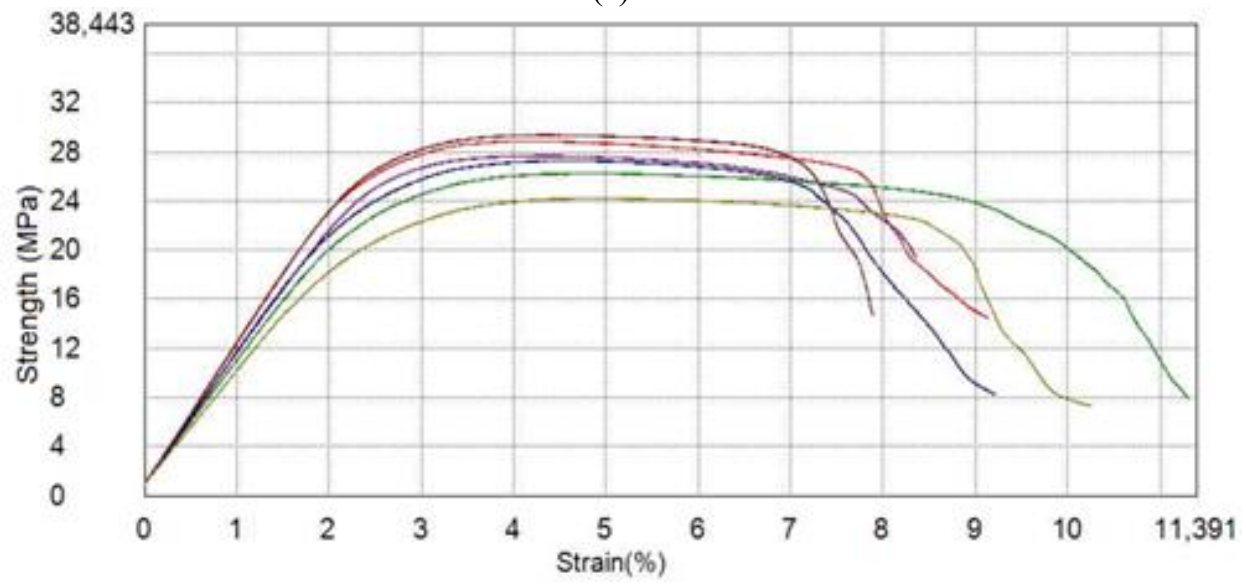

(b)

Figure 7. Stress-strain diagrams of 3-point bending tests for samples manufactured from different parameters a) PLA material, b) ABS material

\section{Conclusions}

In the study, tensile, compression and three-point bending test specimens were produced through FDM additive manufacturing method with PLA and ABS type filament in accordance with the standards. The direct effects of parameters such as layer thickness, filling ratio and nozzle temperature on mechanical properties were investigated. The mechanical properties of PLA and ABS materials are also compared. According to the findings obtained from the experimental results, it has been observed that the increase in the filling rate improves the mechanical properties. The best mechanical properties belong to test specimens made of PLA material. ABS materials have the highest strain, and still the analysis results show that it is the lowest strength as compare PLA material. However, their properties depend on the reinforcing agent which is added to binding. In future studies, estimation or regression analysis regarding the surface quality can be examined via big data and artificial intelligence algorithms by expanding the number of materials used in the study and changing the process parameters. 


\section{References}

Abeykoon, C., Sri-Amphorn, P., \& Fernando, A. (2020). Optimization of fused deposition modeling parameters for improved PLA and ABS 3D printed structures. International Journal of Lightweight Materials and Manufacture, 3(3), 284-297.

Allevi, G., Capponi, L., Castellini, P., Chiariotti, P., Docchio, F., Freni, F., ... \& Tomasini, E. P. (2019). Investigating additive manufactured lattice structures: a multi-instrument approach. IEEE Transactions on Instrumentation and Measurement, 69(5), 2459-2467.

Boğa, C., Seyedzavvar, M., \& Zehir, B. (2021). Experimental investigation on the effects of internal architecture on the mechanical properties of 3D printed PLA components. European Journal of Science and Technology, (24), 119-124.

Burns, M., Rapid Prototyping: System Selection \& Implementation Guide, Managent Rountable, Massachusetts, 1991.

Caminero, M. Á., Chacon J. M. et al. (2019). Additive manufacturing of PLA-based composites using fused filament fabrication: Effect of graphene nanoplatelet reinforcement on mechanical properties, dimensional accuracy and texture, Polymers, 11 (5), 799.

Celebi, A., Gulizia, S., Doblin, C., Fraser, D., Prentice, L. (2020). Characterization of tantalum-titanium powders with universal powder bed (UPB) system for electron beam melting Process. Russian Journal of Non-Ferrous Metals, 61(3), 346-353.

Çelik, S., \& Gür, Y. (2021). The effect of printing parameters on mechanical properties of ABS and carbon fibre reinforced ABS composites fabricated with 3D printer. Journal of Ballkesir University Institute of Science and Technology, 23(1), 200-209.

Çevik, Z. A., Özsoy, K., Erçetin, A. (2021). The effect of machining process on the physical and surface morphology of Ti6Al4V specimens produced through powder bed fusion additive manufacturing, International Journal of $3 D$ Printing Technologies and Digital Industry, 5(2), 187-194.

Damodaran, A., Sugavaneswaran, M. \& Lessard, L. (2021). An overview of additive manufacturing technologies for musical wind instruments. SN Applied Sciences, 3, 162.

Demiray M.A., Şekerci B., Saltık O., Kayacan M.C. (2018). Eklemeli İmalat Yöntemlerinde Kullanılan Malzemeler. 3. Uluslararası $3 B$ Baskl Teknolojileri ve Dijital Endüstri Kongresi, s.93.

Ertugrul, I., Akkus, N., Aygul, E., Yalcınkaya, S. (2020). MEMS Fabrication Using 2PP Technique Based 3D Printer. International Journal of $3 D$ Printing Technologies and Digital Industry, 4(1), 12-17.

Gardan, J. (2016). Additive manufacturing technologies: state of the art and trends. International Journal of Production Research, 54(10), 3118-3132.

Grabowik, C., Kalinowski, K., Ćwikła, G., Paprocka, I., \& Kogut, P. (2017). Tensile tests of specimens made of selected group of the filament materials manufactured with FDM method. In MATEC Web of Conferences, 112, Page 04017. EDP Sciences.

Gür, Y. (2021). Fabrication of an anatomical foot bone structure from computerised tomography data by an ultraviolet led 3D printer. European Journal of Science and Technology, (22), 128-133.

Jiang, J., Hu, G., Li, X., Xu, X., Zheng, P., \& Stringer, J. (2019). Analysis and prediction of printable bridge length in fused e-ISSN: 2148-2683 deposition modelling based on back propagation neural network. Virtual and Physical Prototyping, 14(3), 253-266.

Jiang, J.; Xu, X.; Stringer, J. Support Structures for Additive Manufacturing: A Review. J. Manuf. Mater. Process. 2018, 2, 64.

Kaptan, A., \& Kartal, F. (2020). The effect of fill rate on mechanical properties of PLA printed samples. Journal of the Institute of Science and Technology, 10(3), 1919-1927.

Kuznetsov, V. E., Solonin, A. N., Urzhumtsev, O. D., Schilling, R., \& Tavitov, A. G. (2018). Strength of PLA components fabricated with fused deposition technology using a desktop $3 \mathrm{D}$ printer as a function of geometrical parameters of the process. Polymers, 10(3), 313.

Khuong, T. L., Gang, Z., Farid, M., Yu, R., Sun, Z. Z., \& Rizwan, M. (2014). Tensile strength and flexural strength testing of acrylonitrile butadiene styrene (ABS) materials for biomimetic robotic applications. In Journal of Biomimetics, Biomaterials and Biomedical Engineering, 20, 11-21.

Küçükoğlu, A., Yüce, C., Karpat, F., Okar, H. İ., Sözer, İ. E., \& Kurt, N. (2021). Investigation of the process parameters on the laser transmission welding of PMMA and ABS materials. Uludağ University Journal of the Faculty of Engineering, 26(2), 481-492.

Nagesha, B. K., Dhinakaran, V., Shree, M. V., Kumar, K. M., Chalawadi, D., \& Sathish, T. (2020). Review on characterization and impacts of the lattice structure in additive manufacturing. Materials Today: Proceedings, 21, 916-919.

Palic, N., Zivic, F. et al. (2019). Mechanical behaviour of small load bearing structures fabricated by 3D printing, Applied Engineering Letters: Journal of Engineering and Applied Sciences, 4, 88-92.

Pilipović, A., Raos, P., \& Šercer, M. (2009). Experimental analysis of properties of materials for rapid prototyping. The International Journal of Advanced Manufacturing Technology, 40(1), 105-115.

Sood, A. K., Ohdar, R. K., \& Mahapatra, S. S. (2012). Experimental investigation and empirical modelling of FDM process for compressive strength improvement. Journal of Advanced Research, 3(1), 81-90.

Stratasys, 1998. Erişim Tarihi: 23.11.2018 http://www.stratasys.com/Technology.aspx

Svensson, E., (2017). Material characterization of 3D-printed energy-absorbent polymers inspired by nature, Master Thesis, Chalmers University of Technology Department of Materials and Manufacturing Technology, Sweden.

Tofail, S. A., Koumoulos, E. P., Bandyopadhyay, A., Bose, S., O’Donoghue, L., \& Charitidis, C. (2018). Additive manufacturing: scientific and technological challenges, market uptake and opportunities. Materials today, 21(1), 2237.

Yeşil, Ö., \& Mazanoğlu, K. (2018). Effects of filling ratio, orientation and print temperature on bending properties of $3 \mathrm{~d}$ printed PLA beams. Usak University Journal of Engineering Sciences, 1(2), 66-75. 